\title{
Commentary: Surgery postponed, reason unclear
}

\section{David P. Bichell, MD}

It is routine precaution at most centers to delay cardiac surgery for an infant if a preoperative viral screen is positive. Incomplete data drive this precautionary custom, which is based largely on the behavior of respiratory syncytial virus (RSV). ${ }^{1}$ The standard screening polymerase chain reaction probe detects viral nucleic acids from adenovirus, parainfluenza, influenza, and rhinovirus/enterovirus, in addition to RSV. RSV is uncommonly detected in preoperative screening compared with other, more common viruses in the probe, notably rhinovirus and enterovirus. ${ }^{2}$ Rhinovirus is the most common viral pathogen associated with the common cold and respiratory tract infection in infants and young children, and virus can be shed long after the resolution of any symtoms. ${ }^{3}$ Important incompletely answered questions include: Do viral species other than RSV pose sufficient risk to warrant delay of cardiac surgery? Are there procedural groups whose course is less affected by a positive viral probe, for whom surgery can safely proceed? and, Does a virus-shedding asymptomatic patient have similar risk as a symptomatic patient? A common scenario in the preoperative clinic today is an asymptomatic infant with elective surgery scheduled, a screening probe that is positive for rhinovirus/enterovirus, and the question of whether to proceed or delay.

Giffin and colleagues ${ }^{4}$ start to address some of the unanswered questions. Postulating that recent improvements in cardiopulmonary bypass and respiratory support may change the clinical relevance of a positive viral probe, the authors challenge the custom of delaying surgery. It is a

\footnotetext{
From the Department of Cardiac Surgery, Monroe Carell, Jr. Children's Hospital, Vanderbilt University Medical Center, Nashville, Tenn.

Disclosures: The author reported no conflicts of interest.

The Journal policy requires editors and reviewers to disclose conflicts of interest and to decline handling or reviewing manuscripts for which they may have a conflict of interest. The editors and reviewers of this article have no conflicts of interest.

Received for publication April 11, 2021; revisions received April 11, 2021; accepted for publication April 12, 2021; available ahead of print May 12, 2021.

Address for reprints: David P. Bichell, MD, Department of Cardiac Surgery, Monroe Carell, Jr. Children's Hospital, Vanderbilt University Medical Center, 5247 Doctors' Office Tower, 2200 Children's Way, Nashville, TN $37232-9292$ (E-mail: david.bichell@vanderbilt.edu).

JTCVS Open 2021;6:220-1

2666-2736

Copyright (C 2021 The Author(s). Published by Elsevier Inc. on behalf of The American Association for Thoracic Surgery. This is an open access article under the CC BY-NC-ND license (http://creativecommons.org/licenses/by-nc-nd/4.0/).

https://doi.org/10.1016/j.xjon.2021.04.004
}

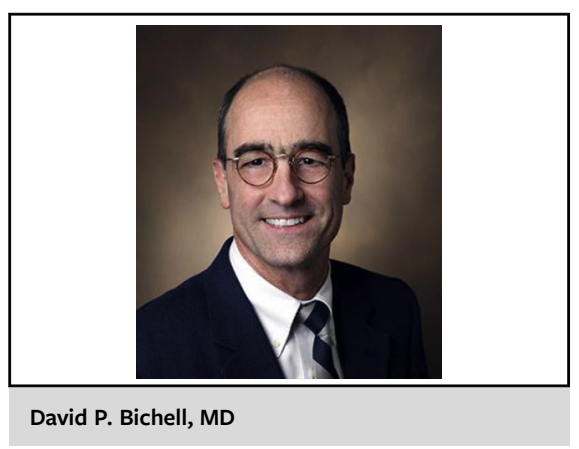

CENTRAL MESSAGE

Precautionary custom drives the postponement of elective cardiac surgery for infants with a positive preoperative viral probe. Data are insufficient to validate the custom for the most common viral species detected by the probe.

retrospective study of infants with active, probe-positive viral respiratory infection, and shows no significant difference in mortality or hospital length of stay for patients undergoing operation in the setting of active infection, compared with procedurally matched uninfected patients. Intensive care stay and noninvasive respiratory support was longer for the infected patients. A majority of the study patients had rhinovirus/enterovirus as identified pathogens, and only 2 had RSV. The study was underpowered to examine the relevance of individual viral species and was underpowered to examine complications arising in procedural groups at special risk, such as those undergoing single-ventricle palliation, where the question commonly arises.

Various studies, also mostly underpowered for subanalysis by viral species or procedural risk, support the general concept that viral respiratory infection may complicate or lengthen the postoperative course following open heart surgery, but fail to address the common question of the asymptomatic patient with non-RSV viral shedding. ${ }^{5-8}$ These studies either look exclusively at RSV, ${ }^{5,8}$ describe particular risk for those with RSV among viral species studied, include rhinovirus/enterovirus, but only symptomatic patients, ${ }^{6}$ or study rhinovirus infection in particular, but only postoperatively. 
There appear to be sufficient data, enduring over decades, to suggest that RSV deserves attention and delay of elective surgery. But RSV is not the dominant virus detected in today's preoperative clinic, and data separating risk by non-RSV viral species are scant. Data remain insufficient to provide guidance for the common scenario of asymptomatic or mildly symptomatic patients shedding non-RSV respiratory virus.

\section{References}

1. Khongphatthanayothin A, Wong PC, Samara Y, Newth CJ, Wells WJ, Starnes VA, et al. Impact of respiratory syncytial virus infection on surgery for congenital heart disease: postoperative course and outcome. Crit Care Med. 1999;27:1974-81.

2. Zhang D, Lou X, Yan H, Pan J, Mao H, Tang H, et al. Respiratory virus associated with surgery in children patients. Respir Res. 2019;20:126.

3. Toivonen L, Schuez-Havupalo L, Karppinen S, Teros-Jaakkola T, Rulli M, Mertsola J, et al. Rhinovirus infections in the first 2 years of life. Pediatrics. 2016;138:e20161309.
4. Giffin NA, Guerra G, Robinson J, Joynt C, Rebeyka I, Sivarajan VB. Impact of early surgical correction or palliation of congenital heart defects in infants with symptomatic viral respiratory tract infections in the current era. J Thorac Cardiovasc Surg Open. 2021;6:211-9.

5. Spaeder MC, Carson KA, Vricella LA, Alejo DE, Holmes KW. Impact of the vira respiratory season on postoperative outcomes in children undergoing cardiac surgery. Pediatr Cardiol. 2011;32:801-6.

6. Moynihan K, Barlow A, Alphonso N, Anderson B, Johnson J, Nourse C, et al Impact of viral respiratory pathogens on outcomes after pediatric cardiac surgery. Pediatr Crit Care Med. 2017;18:219-27.

7. Li X, Wang X, Li S, Zeng M, Li D. Viral respiratory infection, a risk in pediatric cardiac surgery: a propensity-matched analysis. Pediatr Crit Care Med. 2020;21: e431-40.

8. Altman CA, Englund JA, Demmler G, Drescher KL, Alexander MA, Watrin C, et al. Respiratory syncytial virus in patients with congenital heart disease: a contemporary look at epidemiology and success of preoperative screening. Pediatr Cardiol. 2000;21:433-8.

9. Delgado-Corcoran C, Witte MK, Ampofo K, Castillo R, Bodily S, Bratton SL. The Impact of human rhinovirus infection in pediatric patients undergoing heart surgery. Pediatr Cardiol. 2014;35:1387-94. 